\title{
Trichoderma species occurring on wood with decay symptoms in mountain forests in Central Europe: genetic and enzymatic characterization
}

\author{
Lidia Blaszczyk $^{1}$ - Judyta Strakowska ${ }^{1}$ - Jerzy Chekkowski ${ }^{1}$. \\ Agnieszka Gąbka-Buszek ${ }^{1}$ • Joanna Kaczmarek ${ }^{1}$
}

Received: 27 July 2015 / Revised: 23 September 2015 / Accepted: 2 November 2015 / Published online: 19 November 2015

(C) The Author(s) 2015. This article is published with open access at Springerlink.com

\begin{abstract}
The aim of this study was to explore the species diversity of Trichoderma obtained from samples of wood collected in the forests of the Gorce Mountains (location A), Karkonosze Mountains (location B) and Tatra Mountains (location C) in Central Europe and to examine the cellulolytic and xylanolytic activity of these species as an expression of their probable role in wood decay processes. The present study has led to the identification of the following species and species complex: Trichoderma atroviride P. Karst., Trichoderma citrinoviride Bissett, Trichoderma cremeum P. Chaverri \& Samuels, Trichoderma gamsii Samuels \& Druzhin., Trichoderma harzianum complex, Trichoderma koningii Oudem., Trichoderma koningiopsis Samuels, C. Suárez \& H.C. Evans, Trichoderma longibrachiatum Rifai, Trichoderma longipile Bissett, Trichoderma sp. (Hypocrea parapilulifera B.S. Lu, Druzhin. \& Samuels), Trichoderma viride Schumach. and Trichoderma viridescens complex. Among them, T. viride was observed as the most abundant species ( $53 \%$ of all isolates) in all the investigated locations. The Shannon's biodiversity index $(\mathrm{H})$, evenness (E), and the Simpson's biodiversity index (D) calculations for each location showed that the highest species diversity and evenness were recorded for location A-Gorce Mountains $\left(\mathrm{H}^{\prime}=1.71\right.$,
\end{abstract}

Communicated by: Agnieszka Szalewska-Palasz

Lidia Błaszczyk and Judyta Strakowska contributed equally to this work.

Electronic supplementary material The online version of this article (doi:10.1007/s13353-015-0326-1) contains supplementary material, which is available to authorized users.

Lidia Błaszczyk

lgol@igr.poznan.pl

1 Institute of Plant Genetics, Polish Academy of Sciences, Strzeszyńska 34, 60-479 Poznań, Poland
$E=0.82, D=0.79$ ). The preliminary screening of 119 Trichoderma strains for cellulolytic and xylanolytic activity showed the real potential of all Trichoderma species originating from wood with decay symptoms to produce cellulases and xylanases - the key enzymes in plant cell wall degradation.

Keywords Cellulases · Molecular identification · ITS1 · ITS2 rRNA $\cdot$ tef $1 \cdot$ Xylanases

\section{Introduction}

Species of the ascomycete genus Trichoderma (teleomorph Hypocrea) are found in many ecosystems, but the most common and natural habitat of these fungi is known to be soil (Druzhinina et al. 2011). The occurrence of Trichoderma spp. in various soils, such as agricultural, forest, prairie, desert or salt marsh, of all climatic zones, has been the subject of several investigations (Druzhinina et al. 2011; Kubicek et al. 2008). Recent studies based on hight-throughput sequencing (Buee et al. 2009; Lim et al. 2010) and metagenomic analysis (Friedl and Druzhinina 2012; Hagn et al. 2007; Meincke et al. 2010) have revealed that soil is colonized by only a relatively small portion of Hypocrea/Trichoderma species, notably Trichoderma asperellum Samuels, Lieckf. \& Nirenberg, Trichoderma harzianum complex, Trichoderma hamatum (Bonord.) Bainier, Trichoderma atoviride P. Karst., Trichoderma virens (J.H. Mill., Giddens \& A.A. Foster) Arx, Trichoderma lonibrachiatum Rifai, Trichoderma gamsii Samuels \& Druzhin., Trichoderma citinoviride Bissett, Trichoderma koningiopsis Samuels, C. Suárez \& H.C. Evans, Trichoderma spirale Bissett and Trichoderma koningii Oudem., which are known to generally have outstandingly high opportunistic potential. These species succeed in various 
heterotrophic interactions exhibiting saprotrophic and mycoparasitic (necrotrophic hyperparasitism, mycotrophy) lifestyles (Druzhinina et al. 2011).

As saprotrophs, Trichoderma have been considered to make a contribution to the degradation of plant debris, wood and bark (Klein and Eveleigh 1998). Plant biomass is mainly composed of cellulose (insoluble fibers of $\beta$-1,4-glucan), hemicellulose (xylans, mannans) and lignin (a complex polyphenolic structure), which together with proteins, fats, waxes, terpenes, phenols, alcohols and alkanes form the complex and rigid structure of the plant cell walls. Degradation of plant cell wall biopolymers is a complex process, which requires the synergistic action of a large number of extracellular enzymes. Several Trichoderma species, especially Trichoderma reesei, are known to be producers of cellulolytic and hemicellulolytic enzymes (Druzhinina et al. 2010; Gusakov 2011; Kubicek 2013). However, Trichoderma species are not able to decompose non-decayed wood lignocelluloses (Fukasawa et al. 2005, 2011). The utilization of cellulose and hemicellulose by Trichoderma spp. is possible only after preliminary depolymerization and mineralization of lignin by Basidio- and Ascomycetous white rot fungi (Aro et al. 2005; Fuksawa et al. 2005; 2011). Trichoderma spp. are perceived to interfere antagonistically with the primary wood decomposers, either via competition for nutrients and space substrate colonization or by using mechanisms of antibiosis and mycoparasitism (Jaklitsch 2009; Rossman 1996). A comparative analysis of the genome, secretome and transcriptome inventory of T. atroviride, T. virens and Trichoderma reesei indicated that mycoparasitism is the initial (ancestral) lifestyle of Trichoderma (Atanasova et al. 2013; Druzhinina et al.; 2012; Kubicek et al. 2011) whereas saprophytism on predegraded wood is suggested to be the result of the subsequent and alternative nutrient specialization of this fungus (Atanasova et al. 2013; Druzhinina et al. 2012; Kubicek et al. 2011). This hypothesis has been applied in particular to the best known saprotrophic $T$. reesei species, i.e. wild-type isolate QM 6a, which is extremely specialized in the degradation of plant cell wall cellulose and hemicellulose (Druzhinina et al. 2010; Kubicek 2013). It is worth noting that $T$. reesei has very rarely been detected in the natural environment. Only its teleomorphic stages (Hypocrea jecorina) and associated Trichoderma parareesei nom. prov. have been found worldwide in pantropical climatic zones (Druzhinina et al. 2010; Lieckfeld et al. 2000). Among the other Trichoderma species, the ability to produce the cellulase and hemicellulase complex has been stated for several strains of $T$. harzianum complex, T. koningii, T. longibrachiatum, T. viride, T. virens and T. citrinoviride (Strakowska et al. 2014). These species are known to have a pan-global distribution, although some of them occur frequently in temperate regions (Kubicek et al. 2008; Migheli et al. 2009). In our previous study on the occurrence and diversity of Trichoderma in Poland (Central
Europe), five of the above-mentioned species (T. harzianum complex, T. koningii, T. longibrachiatum, T. viride and T. citrinoviride) were also isolated, mostly from pieces of decaying wood (Błaszczyk et al. 2011). Furthermore, decaying wood was found to be one of the most diverse habitats (nine species) from which the most isolates (75 isolates) were collected. Therefore, the objective of the present research was to explore the species diversity of Trichoderma obtained from samples of wood collected in the forests of the Gorce Mountains (location A), Karkonosze Mountains (location B) and Tatra Mountains (location C) in Central Europe and to examine the cellulolytic and xylanolytic activities of these species as an expression of their probable role in wood decay processes.

\section{Materials and methods}

\section{Fungal collection}

The 119 Trichoderma strains investigated in this study were obtained from samples of decaying wood collected in the forests of the Tatra Mountains, Gorce Mountains and Karkonosze Mountains, located in Central Europe in Poland (Table 1). Fifteen Trichoderma strains had previously been identified at the species level by Jelen et al. (2014). One hundred and four Trichoderma isolates were described in this paper. All the studied Trichoderma strains are deposited in the collection of the Institute of Plant Genetics, Polish Academy of Science, Poznań, Poland, and are available to the scientific community.

\section{Study site, strain isolation and maintenance}

The pieces of decaying wood were collected in July 2009, 2010 and 2011 from the floor of forests in the Tatra Mountains (The Tatra National Park), Gorce Mountains (The Gorce National Park) and Karkonosze Mountains (The Karkonosze National Park) located in Central Europe (Fig. 1). The Tatra National Park $\left(49^{\circ} 10^{\prime} \mathrm{N} 19^{\circ} 55^{\prime} \mathrm{E}\right)$ and The Gorce National Park $\left(49^{\circ} 35^{\prime} \mathrm{N} 20^{\circ} 3^{\prime} \mathrm{E}\right)$ are located in the Carpathian Mountains in Southern Poland. The Tatra National Park is a high mountain national park, ranging from 900 to $2500 \mathrm{~m}$ a.s.l., and including vegetation belts from the lower mountain to the alpine zones. The park covers an area of $211.64 \mathrm{~km}^{2}$, of which $151.91 \mathrm{~km}^{2}$ is forested. The climate is cool and moderately wet. The annual precipitation level is $1800 \mathrm{~mm} \mathrm{yr}^{-1}$. The average annual temperature is $2-5^{\circ} \mathrm{C}$ (Hess 1996; Savva et al. 2006). The Gorce Mts. are relatively low, where the highest peaks exceed $1310 \mathrm{~m}$ a.s.l. The area of the Gorce National Park is $70.3 \mathrm{~km}^{2}$, of which $65.91 \mathrm{~km}^{2}$ is forested. The average annual precipitation varies from $700 \mathrm{~mm} \mathrm{yr}^{-1}$ in the foothills to $1200 \mathrm{~mm}$ $\mathrm{yr}^{-1}$ at the highest points (Miczyński 2006). The average 
Table 1 Trichoderma isolates originated from decaying wood in forests mountains in Poland

\begin{tabular}{|c|c|c|c|}
\hline \multirow[t]{2}{*}{ Species } & \multirow[t]{2}{*}{ Culture/strain code } & \multicolumn{2}{|c|}{ NCBI GenBank accession No. ${ }^{a}$} \\
\hline & & ITS & tefl \\
\hline \multicolumn{4}{|l|}{ Location $^{\mathrm{b}} \mathrm{A}$} \\
\hline T. atroviride & AN497 & JX184119 & JX184096 \\
\hline T. citrinoviride & $\underline{\mathrm{AN} 393^{\mathrm{C}}}, \mathrm{AN} 490, \mathrm{AN} 710$ & JX184109 & JX184086 \\
\hline T. cremeum & AN392 & JX184117 & JX184094 \\
\hline T. harzianum complex: (T. harzianum) & AN394 & JX184113 & JX184090 \\
\hline T. longibrachiatum & AN488 & JX184118 & JX184095 \\
\hline T. koningii & AN398, AN399 & JX184126 & JX184106 \\
\hline T. paraviridescens & AN387, $\underline{\text { AN405, }}$ AN492, AN494, AN709 & JX184127 & JX184103 \\
\hline T. trixiae & AN388 & JX184128 & JX184104 \\
\hline \multirow[t]{3}{*}{ T. viride } & AN397, AN402, AN493, AN496 & JX184121 & JX184098 \\
\hline & AN389, AN395, AN401 & JX184122 & JX184099 \\
\hline & AN390, AN487 & JX184123 & JX184101 \\
\hline \multicolumn{4}{|l|}{ Location B } \\
\hline T. citrinoviride & AN499, $\underline{\text { AN500 }}$ & JX184109 & JX184086 \\
\hline T. atroviride & AN240 & JX184119 & JX184096 \\
\hline T. koningiopsis & AN251 & HQ292939 & HQ292993 \\
\hline T. viridescens complex: (T. paraviridescens) & 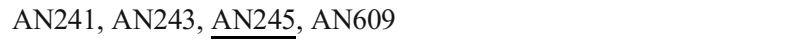 & JX184127 & JX184103 \\
\hline (T. trixiae) & $\underline{\mathrm{AN} 248}$ & JX184128 & JX184104 \\
\hline (T. viridarium) & AN605 & JX184125 & JX184102 \\
\hline \multirow[t]{3}{*}{ T. viride } & $\underline{\mathrm{AN} 242}, \underline{\mathrm{AN} 250}, \underline{\mathrm{AN} 255}, \mathrm{AN} 604$ & JX184121 & JX184098 \\
\hline & AN244, AN249, AN810, AN813, AN826 & JX184122 & JX184099 \\
\hline & AN247, AN252, AN253, AN802, AN806, AN814, AN827 & JX184123 & JX184101 \\
\hline \multicolumn{4}{|l|}{ Location $\mathrm{C}$} \\
\hline T. atroviride & AN705 & JX184119 & JX184097 \\
\hline T. citrinoviride & $\underline{\text { AN303b }}$, AN477 & JX184109 & JX184086 \\
\hline T. gamsii & AN327, AN385 & JX184130 & JX184107 \\
\hline \multirow[t]{2}{*}{ T. harzianum complex: (T. harzianum) } & AN312, AN360, AN367,AN369, AN373, AN381, AN415, AN479, & JX184113 & JX184090 \\
\hline & AN349, AN480 & JX184111 & JX184089 \\
\hline (T. atrobrunneum) & AN364, AN699, AN370, AN704, AN706 & JX184112 & JX184088 \\
\hline T. longipile & AN359, AN414 & JX184115 & JX184091 \\
\hline T. viridescens complex: (T. paraviridescens) & $\mathrm{AN} 322, \underline{\mathrm{AN} 323}, \mathrm{AN} 328, \mathrm{AN} 334, \mathrm{AN} 702$ & JX184127 & JX184103 \\
\hline (T. trixiae) & AN308, $\underline{\text { AN366, AN416 }}$ & JX184128 & JX184104 \\
\hline \multirow[t]{4}{*}{ T. viride } & $\begin{array}{l}\text { AN310, AN330, AN350, AN332, AN340, AN357, AN356, } \\
\text { AN358, AN361, AN378, AN384, AN419, AN421, AN478 }\end{array}$ & JX184123 & JX184101 \\
\hline & $\begin{array}{l}\text { AN315, AN320, AN351, AN352, AN355, AN354, AN371, AN374, } \\
\text { AN376, AN377, AN379, AN382, AN383, AN472, AN474, } \\
\text { AN475, AN485, AN484, AN687, AN690, AN701 }\end{array}$ & JX184121 & JX184098 \\
\hline & AN346 & JX184124 & JX184100 \\
\hline & AN347, AN420 & JX184122 & JX184099 \\
\hline Trichoderma sp. & AN471 & JX184114 & JX184093 \\
\hline
\end{tabular}

${ }^{a}$ the same NCBI GenBank Accession number assigned to the isolates possessing identical alleles in the locus ITS or tef1

${ }^{\mathrm{b}}$ Location A-Gorce Mountains, location B-Karkonosze Mountains, location C-Tatra Mountains

${ }^{\mathrm{c}}$ underline indicates the isolates identified previously at the species level by a combination of morphological and molecular analyses by Jelen et al. (2014)

annual air temperature varies along the mountains' longitudinal profile from 6 to $7^{\circ} \mathrm{C}$ at the foot of the range to $3^{\circ} \mathrm{C}$ along the ridges (Hess 1965). The Karkonosze National Park is located in southwestern Poland, in the Karkonosze Mountains. The park, with an area of $55.76 \mathrm{~km}^{2}$, protects the highest part of the Sudeten massif, including Mount Śnieżka, which 
Fig. 1 Map displaying the three mountain sampling sites used in this study: A-Gorce Mountains (location A), B-Karkonosze Mountains (location B), C-Tatra Mountains (location C)

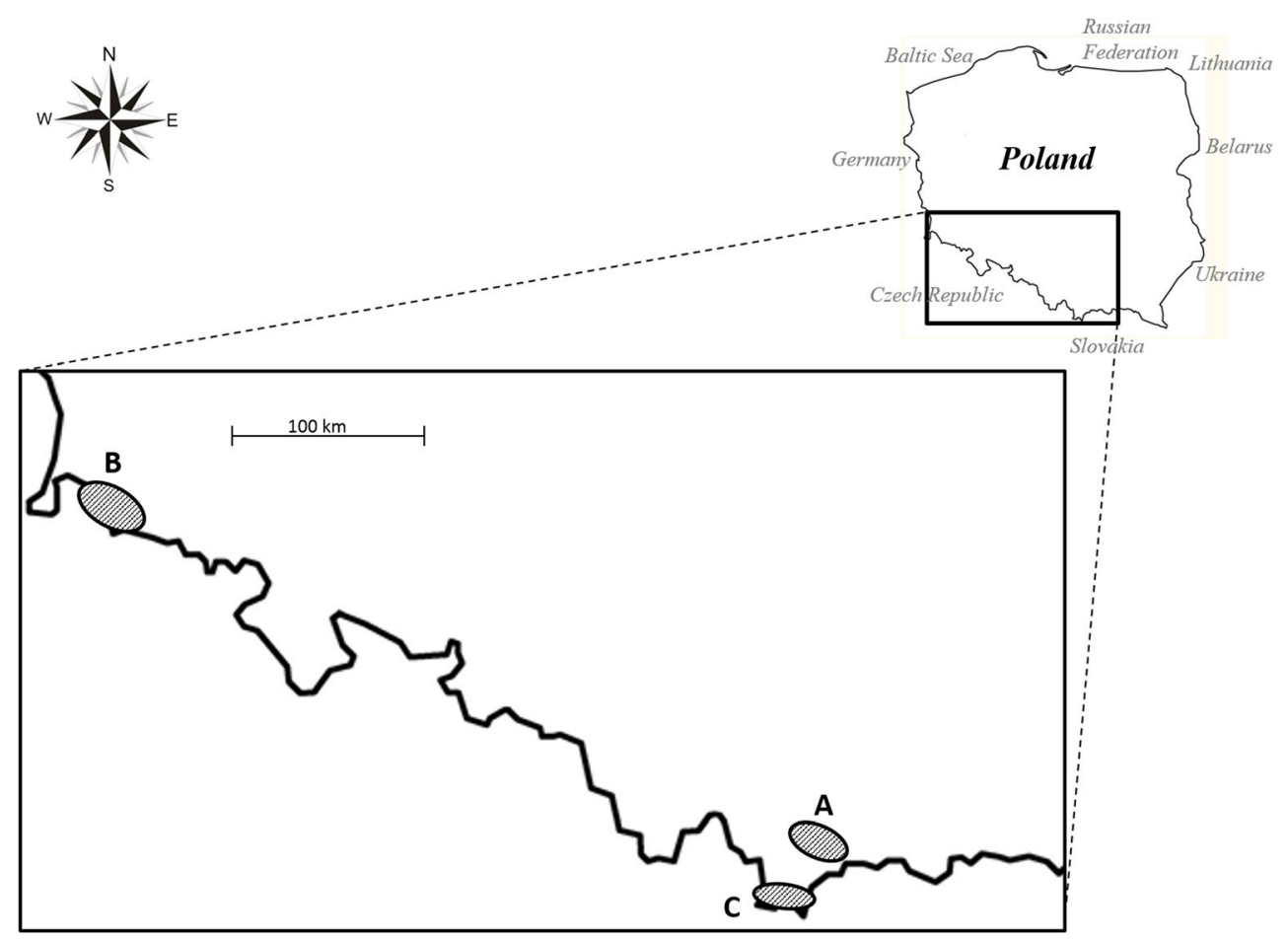

reaches a height of $1602 \mathrm{~m}$ a.s.l. The climate of the Karkonosze is controlled by maritime polar air masses derived from the Atlantic Ocean, which give rise to a local alpine climate. Average total annual precipitation ranges from $1042 \mathrm{~mm} \mathrm{yr}^{-1}$ at lower elevations to $1102 \mathrm{~mm} \mathrm{yr}^{-1}$ on Mount Śnieżka. The average annual temperature is $1-7.4^{\circ} \mathrm{C}$ (Migała 2005). Karkonosze National Park in Poland and the Krkonoše National Park in the Czech Republic constitute a cross-border biosphere reserve within the framework of the UNESCO Man and the Biosphere Programme (UNESCO 2011).

The pieces of wood with white or brown rot were packed in paper bags, dried at room temperature if wet, and stored until isolation. In the laboratory, small sterile samples $(0.5 \times 0.2 \mathrm{~cm})$ were taken from each piece of wood, plated on Synthetischer Nährstoffarmer Agar (SNA, Nirenberg 1976) and incubated at $20{ }^{\circ} \mathrm{C}$ for 6 days. All colonies resembling Trichoderma were twice subcultured on potato dextrose agar (PDA, Oxoid, UK) and incubated as above. Pure cultures were subsequently transferred to tubes containing SNA and stored at $4{ }^{\circ} \mathrm{C}$ for further study.

\section{Identification of Trichoderma}

Trichoderma isolates obtained in this study were identified at the species level by a combination of morphological and molecular analyses. The morphological characteristics were based on the key by Gams and Bissett (1998) and Chaverri et al. (2015). Colony characteristics were examined in cultures grown on PDA and SNA, after 14 days incubation at a temperature of $25{ }^{\circ} \mathrm{C}$. Microscopic observations were performed in cultures grown on SNA. The molecular identification was based on the sequencing of internally transcribed spacer regions 1 and 2 (ITS1 and ITS2) of the rRNA gene cluster and a fragment of the translation-elongation factor 1-alpha (tef1) gene. Mycelium for DNA extraction was obtained as described previously (Błaszczyk et al. 2011). Isolation of total DNA was performed using the CTAB method (Doohan et al. 1998). The ITS1 and ITS2 region of the rDNA gene cluster was amplified using primers ITS4 and ITS5 (White et al. 1990). A fragment of the 1.2-kb tefl gene was amplified using primers Ef728M (Carbone and Kohn 1999) and TEF1LLErev (Jaklitsch et al. 2005). The PCR reactions and electrophoresis were carried out under the conditions described by Błaszczyk et al. (2013). The 0.4-kb ITS and 1.2-kb tefl amplicon purification steps and sequencing were carried out as described by Błaszczyk et al. (2011). Sequences were edited and assembled using Chromas v. 1.43 (Applied Biosystems). For species identification, sequences were subjected to analysis by BLASTn (http://blast.ncbi.nlm.nih.gov/) as well as TrichOKEY and TrichoBLAST (http://www.isth.info; Druzhinina et al. 2005; Kopchinskiy et al. 2005; Chaverri et al. 2015). The comparative analyses were based on the ITS and tefl sequences of the 119 Trichoderma strains determined in this and our previous studies (Jeleń et al. 2014). For comparative analysis, the sequences were aligned using Clustal W program (Thompson et al. 1994). The sequence representing identical allele in the locus of ITS or tefl were grouped together. In each group, only one sequence was selected and deposited in the NCBI GenBank (Table 1). 


\section{Phylogenetic analysis}

The phylogenetic analyses were based on the selected ITS and tefl gene sequences (each allele identified in ITS and tefl locus) obtained in this work as well as on the sequences retrieved from NCBI GenBank (http://www.ncbi.nlm.nih.gov) as the closest matches: DQ109573, EU280135, DQ677646, DQ677647, DQ677648, DQ841735, DQ323428, DQ323431, DQ841745, FJ860726, EU871028, FJ860763, FJ442236, KP115288, FJ442276, KP115287, FJ442273, AY737760, EU280074, FJ860799, EU401564, X93963, DQ672607, DQ672606, DQ672605, EU871012, FJ860611, DQ841725, DQ841721, FJ860642, DQ109549, FJ179578, EU401613, AY737736, KP115273, FJ463360, KJ665699, FJ463289, KP115274, FJ463395, JN175595, EU280051. Fusarium graminearum (CBS 131784: JX162387, JX118997) was chosen as outgroup. DNA sequences were initially aligned with CLUSTAL W (Thompson et al. 1994) and then rechecked and adjusted manually as necessary using MEGA4 software version (Tamura et al. 2007). Phylogenetic relationships were reconstructed with the MEGA4 software version using the maximum parsimony approach (close-neighbor-interchange algorithm with search level 1 in which the initial trees were obtained with the random addition of sequences - ten replicates) with complete deletion option (i.e. all positions containing gaps and missing data were eliminated from the dataset). All reconstructions were tested by bootstrapping with 1000 replicates.

\section{Enzyme production}

Trichoderma reseei QM 9414, sourced from the Czech Collection of Microorganisms (CCM), Brno, Czech Republic was used as the reference strain. The Trichoderma collection of 119 isolates were screened for cellulase and xylanase activity under the same conditions, specifically optimized for cellulase/xylanase production with $T$. reseei QM 9414 strain. Trichoderma isolates were first cultured on PDA medium in Petri dishes for 3 days at $25^{\circ} \mathrm{C}$. Following incubation, the agar discs (4 mm in length, $3 \mathrm{~mm}$ thick) were cut from the sporulated cultures and transferred into $30 \mathrm{~mL}$ of autoclaved induction medium ( $\mathrm{pH}$ 5.5) consisting of (per liter of distilled water) $10 \mathrm{~g}$ carboxymethyl cellulose (CMC, Sigma Aldrich, USA), $2 \mathrm{~g}$ ammonium phosphate, $2 \mathrm{~g}$ potassium orthophosphate, $0.3 \mathrm{~g}$ magnesium sulfate, $0.3 \mathrm{~g}$ calcium chloride, $1 \mathrm{~g}$ bacteriological peptone (Fluka, Switzerland), $2 \mathrm{~g}$ yeast extract (Oxoid, UK), $30 \mathrm{mg}$ libremix (CIDA, UK) and $0.001 \mathrm{~g}$ cobaltous chloride. The incubation was carried out in $100 \mathrm{ml} \mathrm{Er-}$ lenmeyer flasks without shaking at $25^{\circ} \mathrm{C}$ and optimally for 5 days (in the case of cellulase production) and 7 days (in the case of xylanase production). All analyses were done in triplicate.

\section{Assay of enzyme activities}

After culturing in induction medium, mycelial pellets were removed by centrifugation ( $15 \mathrm{~min}$ at $12,000 \mathrm{~g}$ ). Total cellulase activity was determined using the filter paper activity (FPA) assay (Ghose 1987). Whatman No. 1 filter paper (50 mg, $1 \times 6 \mathrm{~cm}$ strip; Whatman International, UK) was incubated for $60 \mathrm{~min}$ in $0.5 \mathrm{~mL}$ of $0.05 \mathrm{M} \mathrm{Na}$-citrate buffer solution ( $\mathrm{pH} 4.8$ ) at $50{ }^{\circ} \mathrm{C}$ with an addition of $0.5 \mathrm{~mL}$ enzyme solution (supernatant). The reaction mixture was incubated at $50{ }^{\circ} \mathrm{C}$ for $15 \mathrm{~min}$. Released reducing sugars were determined by dinitrosalicylic acid reagent (DNS) method of Miller (1959) and Eveleigh et al. (2009), by adding $1 \mathrm{~mL}$ of DNS solution and then incubating the mixture at $95{ }^{\circ} \mathrm{C}$ for $5 \mathrm{~min}$. Absorbance was measured at $540 \mathrm{~nm}$ (UV-1800 Spectrophotometer, Shimadzu, Japan). A calibration curve was established with glucose (POCH, Poland). Final cellulase activity was expressed in filter paper units (FPU) defined as the amount of enzyme which forms $1 \mu \mathrm{mol}$ of glucose per minute under the assay conditions. Three independent experiments were run for each strain (including blanks).

Xylanase activity was determined by measuring the total amount of reducing sugars released from $1 \%(w / v)$ birch wood xylan (Sigma-Aldrich, USA) in $0.5 \mathrm{~mL}$ of $50 \mathrm{mM}$ citrate buffer (pH 4.8), supplemented with $0.5 \mathrm{~mL}$ enzyme solution (supernatant). The reaction mixture was incubated at $50{ }^{\circ} \mathrm{C}$ for $15 \mathrm{~min}$. Released reducing sugars were determined by dinitrosalicylic acid reagent (DNS) method of Miller (1959) and Eveleigh et al. (2009), by adding $1 \mathrm{~mL}$ of DNS solution and then incubating the mixture at $95{ }^{\circ} \mathrm{C}$ for $5 \mathrm{~min}$. Absorbance was measured at $540 \mathrm{~nm}$ (UV1800 Spectrophotometer, Shimadzu, Japan). A standard curve was prepared with d-xylose (Sigma). The results were expressed in units defined as the amount of enzyme releasing $1 \mu \mathrm{mol}$ reducing sugar (measured as xylose) during 1 min under the assay conditions. Three independent experiments were run for each strain (including blanks).

\section{Data analysis}

Shannon's biodiversity index $(\mathrm{H})$ was calculated according to the formula: $\mathrm{H}=-\Sigma \mathrm{pi} *$ lnpi, where pi is the proportion of ith species (Shannon 1948). The Shannon evenness (E) was calculated according to the equation: $\mathrm{E}=\mathrm{H} / \mathrm{lnS}$, where $\mathrm{S}$ is the total number of species. The Simpson's biodiversity index (D) was calculated as $\mathrm{D}=1-\Sigma \mathrm{ini}(\mathrm{ni}-1) \mathrm{i} / \mathrm{N}(\mathrm{N}-1)$, where ni represents specimens of a species and $\mathrm{N}$ represents the total number of specimens (Simpson 1949).

The statistical analysis was performed using the programs Statistica version 10.0 (StatSoft Inc.) and Microsoft Excel version 2010. Inference about the significance of differences 
between enzyme activity of isolates was conducted using oneway ANOVA and was determined using Tukey's test $(\alpha=0.05)$.

\section{Results}

\section{Identification of Trichoderma}

One hundred and four Trichoderma isolates obtained from samples of decaying wood collected in the forests of the Tatra Mountains (location C), Gorce Mountains (location A) and Karkonosze Mountains (location B) in Poland were identified at the species level based on morphological as well as ITS1, ITS2 and tef1 sequencing data. Finally, 12 species or species complex were found: T. atroviride, T. citrinoviride, T. cremeum P. Chaverri \& Samuels, T. gamsii, T. harzianum complex, T. koningii, T. koningiopsis, T. longibrachiatum, T. longipile Bissett, Trichoderma sp. (H. parapilulifera B.S. $\mathrm{Lu}$, Druzhin. \& Samuels), T. viride Schumach. and T. viridescens complex. Furthermore, the tefl sequences analysis of the isolates belonging to the T. harzianum species complex and $T$. viridescens species complex revealed five isolates as Trichoderma atrobrunneum F.B. Rocha, P. Chaverri \& W. Jaklitsch, 11 isolates as Trichoderma harzianum Rifai, one isolate as Trichoderma viridarium Jaklitsch, Samuels \& Voglmayr, three isolates as Trichoderma trixiae Samuels \& Jaklitsch and ten isolates as Trichoderma paraviridescens Jaklitsch, Samuels \& Voglmayr. The identification, origin and NCBI GenBank accession numbers of all isolates are given in Table 1. In order to determine the relationship among Trichoderma strains originated from decayed wood collected in a mountain forest in Poland and selected from NCBI GenBank as close relatives, the phylogenetic analysis were performed. The results were presented as a consensus ITS tree and tefl tree (Online resource 1,2).

\section{Species diversity and distribution}

The analysis were based on the 119 Trichoderma strains occurring on wood with decay symptoms in mountain forests in Central Europe, identified in this study and published previously by Jelen et al. (2014). Grouping of the species according to their geographic origin, the same number (8) of species was found in location $\mathrm{A}$ and $\mathrm{C}$, with a slightly lower number (5) in location B (Table 1). However, the proportion of isolates obtained from location $\mathrm{C}$ was the highest ( 69 isolates, $58 \%$ ), followed by that recovered from location B (26 isolates, $22 \%$ ) and location A (24 isolates, $20 \%$ ). Some of the species were unique to a particular location-T. cremeum, T. longibrachiatum and $T$. koningii were only collected from location A, T. koningiopsis only from location B and T. gamsii,
T. longipile and Trichoderma sp. (H. parapilulifera) only from location $C$. On the other hand, four species (T. atroviride, T. citrinoviride, T. viride and T. viridescens complex) were found in all the locations. Among the 12 species described in this study, T. viride was the most abundant species (53\% of all isolates). It was also observed as the most dominant fungus in all the locations investigated. Another very common species complex (17\% of all isolates) occurring in the three locations was $T$. viridescens. After $T$. viride and $T$. viridescens complex, T. harzianum was commonly isolated ( $13 \%$ of all isolates) from samples of decaying wood. However, the presence of this species complex was mainly ascertained in location C. Whereas, the other species (T. atroviride, T. citrinoviride, T. cremeum, T. gamsii, T. koningii, T. koningiopsis, $T$. longibrachiatum, T. longipile and H. parapilulifera) were represented by several strains and accounted for the minority of isolates ( $17 \%$ of all isolates).

The obtained data were used to calculate the Shannon's biodiversity index $(\mathrm{H})$, evenness $(\mathrm{E})$ and the Simpson's biodiversity index (D) for each location and the total population. The highest species diversity and evenness were recorded for location A $\left(\mathrm{H}^{\prime}=1.71, E=0.82, D=0.79\right)$. The Shannon and Simpson diversity indexes, estimated for the other two sites showed, that location $\mathrm{C}$ had higher species diversity $\left(\mathrm{H}^{\prime}=\right.$ $1.34, D=0.64)$ than location B $\left(\mathrm{H}^{\prime}=1.08, D=0.58\right)$, while the species evenness measure resulted in $E=0.67$ for location $\mathrm{B}$ and $E=0.64$ for location C. Consequently, location $\mathrm{C}$ was characterized by the least homogenous distribution of species. The overall diversity values for Trichoderma species originating from decaying wood in Polish mountains were $\mathrm{H}^{\prime}=1.53$, $E=0.62$ and $D=0.67$.

\section{Cellulolytic and xylanolytic activities}

A total of 119 Trichoderma isolates - 104 isolates identified in the present paper and 15 isolates described previously by Jelen et al. (2014), belonging to 12 species or species complex and originating from decaying wood collected in Polish mountains, were examined for their ability to produce cellulolytic and xylanolytic enzymes. All of the isolates were able to degrade cellulose (Whatman No. 1 filter paper) and birch wood xylan (Online resource 3). However, the levels of cellulase and xylanase activities were differential both between isolates of the same species (in the case of species represented by at least two isolates, such as T. atroviride, T. gamsii, T. harzianum complex, T. koningii, T. viride, T. viridescens complex) and between species (Figs. 2 and 3). The highest total cellulase activity (FPA) was observed for T. cremeum species, represented by only a single isolate, AN392 (Fig. 2). Also, T. gamsii, especially isolate AN327 $(0.308 \pm 0.006 \mathrm{FPU} / \mathrm{mL})$, and $T$. longibrachiatum species were found to be efficient producers of cellulolytic activity. Trichoderma harzianum 
complex, T. koningii and T. citrinoviride species displayed moderate cellullase activity. A lower cellulose-decomposing potential was recorded for $T$. koningiopsis, $T$ viride, $T$. atroviride, T. longipile, Trichoderma sp. (H. parapilulifera) and $T$. viridescens complex. Considering the diversity within T. atroviride species, cellulase activity ranged from $0.135 \pm$ 0.001 (isolate AN705) to $0.201 \pm 0.035$ (isolate AN240) FPU/mL and within $T$. citrinoviride species, this activity ranged from $0.135 \pm 0.002$ (isolate AN710) to $0.281 \pm 0.009$ (isolate AN303b) FPU/mL. The activity produced by two isolates of T. koningii (AN398 and AN399) was $0.267 \pm 0.001$ and $0.200 \pm 0.028 \mathrm{FPU} / \mathrm{mL}$, respectively. In the set of 16 isolates of T. harzianum complex there were isolates (AN370, AN704, AN364, AN706, AN699) identified as T. atrobrunneum, that showed weak cellulose-decomposing potential, but there were also five isolates of T. harzianum (AN415, AN394, AN373, AN367, AN312) with high decomposition activity towards cellulose (over $0.3 \mathrm{FPU} / \mathrm{mL}$ ). Cellulase activity displayed by isolates belonging to $T$. viridescens species complex ranged from $0.074 \pm 0.003$ (T. paraviridescens AN328) to $0.271 \pm 0.002$ (T. paraviridescens AN702) FPU/ $\mathrm{mL}$. However, the variation in cellulase activity differed significantly among the largest group of $T$. viride isolates, the lowest value being $0.075 \pm 0.004$ (isolate AN340), whereas the highest was as high as $0.283 \pm 0.000 \mathrm{FPU} / \mathrm{mL}$ for isolate AN701.

As shown in Fig. 3, non-significant differences in the xylanase activity were obtained between species. Of all species, T. gamsii was found to be the best producer of xylanolytic activity (over $2.4 \mathrm{U} / \mathrm{mL}$ ), in contrast to T. citrinoviride, which was characterized as the least effective decomposer of xylan (Fig. 3, Online resource 3).

However, the variation in xylanolytic activity differed significantly among the $T$. citrinoviride isolates, the lowest value being $1.147 \pm 0.003 \mathrm{U} / \mathrm{mL}$ (AN710), whereas the highest was $2.396 \pm 0.011 \mathrm{U} / \mathrm{mL}$ (AN499). Similarly, xylanolytic activity varied among isolates of $T$. atroviride from $1.808 \pm 0.003$ (AN 705 ) to $2.519 \pm 0.006$ (AN497) $\mathrm{U} / \mathrm{mL}$. Within T. harzianum species complex, the highest xylanase activity was observed for the T. harzianum AN369 isolate $(2.887 \pm 0.022 \mathrm{U} / \mathrm{mL})$ and the lowest for the T. harzianum AN480 isolate (1.634 $0.001 \mathrm{U} / \mathrm{mL}$ ). Xylanase activities of two T. koningii isolates, AN399 and AN398, were $2.001 \pm 0.0077$ and $2.052 \pm 0.095 \mathrm{U} /$ $\mathrm{mL}$, respectively. Among the 63 isolates of T. viride, the most effective in xylan degradation were three isolates: AN813 $(3.100 \pm 0.016 \mathrm{U} / \mathrm{mL}), \operatorname{AN} 810(3.076 \pm 0.008 \mathrm{U} / \mathrm{mL})$ and AN827 $(3.070 \pm 0.008 \mathrm{U} / \mathrm{mL})$, whereas AN242 was observed to be a weak decomposer of cellulose $(1.227 \pm 0.004 \mathrm{U} / \mathrm{mL})$. In the set of 20 isolates of $T$. viridescens species complex, the highest levels of xylanase activity were achieved by the T. paraviridescens AN702 $(3.099 \pm 0.004 \mathrm{U} / \mathrm{mL})$ and AN609 $(3.070 \pm 0.005 \mathrm{U} / \mathrm{mL})$ and the lowest was presented by the T. paraviridescens AN709 isolate $(0.946 \pm 0.001 \mathrm{U} / \mathrm{mL})$.

\section{Discussion}

The present study yielded a total of 12 species of Trichoderma. Eight Trichoderma species and species complex, namely T. atroviride, T. citrinoviride, T. harzianum complex, T. koningii, T. viride, T. viridescens complex, $T$. koningiopsis and $T$. gamsii, have also been isolated from decaying wood collected in parks and forests of a lowland region of Poland in our preliminary investigations (Błaszczyk et al. 2011). It is worth noting that in contrast to the previous study, where $T$. harzianum was the most frequently isolated species complex from decaying wood, here $T$. viride was observed to be the predominant taxon associated with this microhabitat. The numerous reports on T. viride and its close relative $T$. viridescens species complex in the literature imply a wide geographic distribution for these species, but Samuels (2006), Jaklitsch et al. (2006b) and Jaklitsch (2011) observed it to be more common in north- and south-temperate regions, including Europe (Austria, Czech Republic, England, France, Germany, Northern Ireland, Russia, Sweden), Japan, New Zealand, Canada and the USA. These species have been isolated from various materials, especially from soil, peat, wood and leaf litter. In Europe, the stroma of its teleomorph have been found inconspicuously on wood and bark of cut branches, tree tops or logs of deciduous and coniferous trees (Jaklitsch 2011; Jaklitsch et al. 2013). A recent study of Jaklitsch et al. (2013) provided details of the T. viridescens species complex, including the species identified in the present study, namely $T$. paraviridescens, $T$. trixiae and T. viridarium. Jaklitsch et al. (2013) contend that all these species are known to occur in Europe, although the commonest species of the T. viridescens complex in Europe is T. paraviridescens. Trichoderma viridarium is particularly common in southern Europe. Whereas T. trixiae and exactly its sexual morph has been found only once in Germany in immature condition. As shown here, after $T$. viride and T. viridescens species complex, T. harzianum complex was commonly isolated (13\% of all isolates) from samples of decaying wood. Recently, the taxonomic of T. harzianum species complex was revised to include at least 14 species (Chaverri et al. 2015). Two of these species, namely T. harzianum and T. atrobrunneum, have been identified in the present study. As reported by Chaverri et al. (2015), T. harzianum is an uncommon species known only from Europe and North America, isolated mostly from soil and mushroom compost and occasionally as an endophyte in stems. According to these authors, the geographic distribution of T. atrobrunneum is also restricted to temperate regions (Europe, North America). However, this species has been isolated from soil, decaying wood and other fungi (Chaverri et al. 2015). The other species recognized in the present study, such as T. atroviride, T. citrinoviride, T. longibrachiatum, T. gamsii and $T$. koningiopsis, are known from their evident widespread 


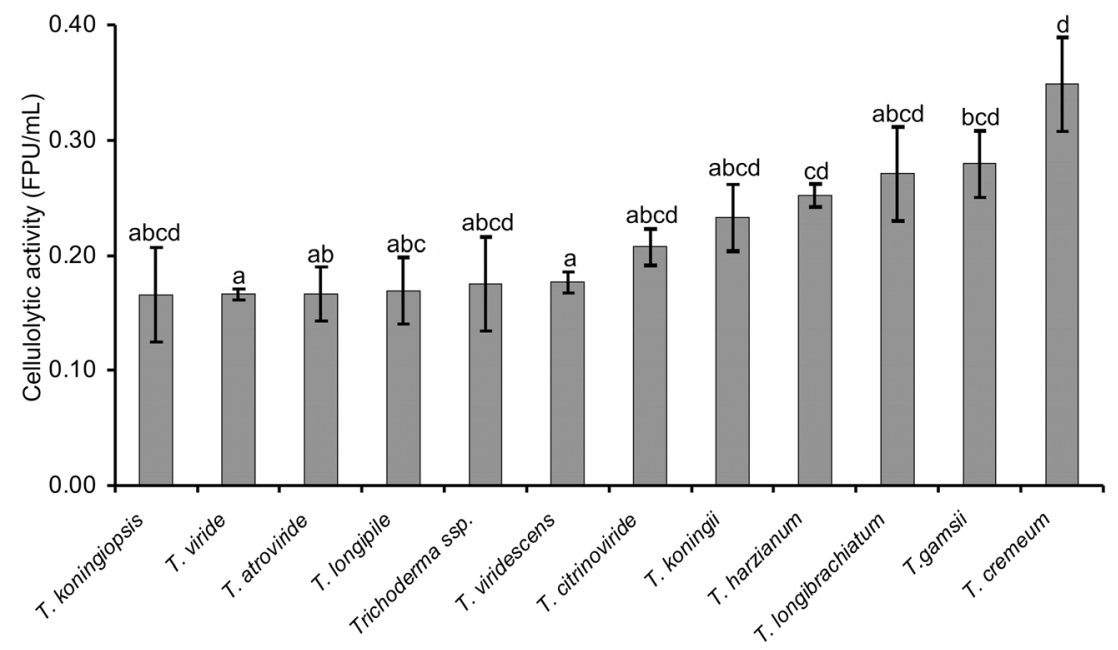

Fig. 2 Total cellulase activity distribution for eight Trichoderma species. Different lowercase letters indicate significant difference in enzymatic activity among species. Bars represent mean \pm standard error. Trichoderma harzianum include isolates T. harzianum and T. atrobrunneum, belonging to the T. harzianum species complex.

occurrence in Europe, North and South America and Asia (Belayneh Mulaw et al. 2010; Hoyos-Carvajal et al. 2009; Jaklitsch 2009, 2011; Kubicek et al. 2003; López-Quintero et al. 2013; Zhang et al. 2005), whereas T. longibrachatum and T. koningiopsis are preferentially isolated from warmer or tropical areas. However, T. koningii and T. longipile exhibit a distribution restricted to Europe and North America (Kubicek et al. 2008). The latter has so far only been isolated from wood of Populus, wood of Ulmus and soil in Europe and Canada (Chaverri et al. 2003; Jaklitsch 2011). A rare species, whose supposed anamorph-Trichoderma isolate AN471-was found in the present study, is $H$. parapilulifera. This species is mainly known from two teleomorphic specimens collected in North America and Europe, and its anomarphic state was
Trichoderma viridescens include isolates $T$. paraviridescens, T. trixiae and $T$. viridarium, belonging to the $T$. viridescens species complex. Bars represent mean \pm standard error of three independent analyses (assay of cellulase activity) for each strain

detected and characterized recently by Jaklitsch (2011). However, there has been little study to date of the occurrence of T. cremeum species, exclusively (isolate AN392) obtained in the present research from decaying wood in the Gorce Mountains (location A). Previously, only its teleomorph (Hypocrea cremea) had been found by Chaverri et al. (2003) in North America and New Zealand.

Our study showed the highest species diversity and evenness at location A (Gorce Mountains), and the lowest levels of species richness at location B (Karkonosze Mountains). We attribute this phenomenon to differences in the biodiversity of trees, and consequently, the type of wood at the different locations. The majority of the Karkonosze National Park consists of forests dominated by Picea abies (L.) H. Karst.

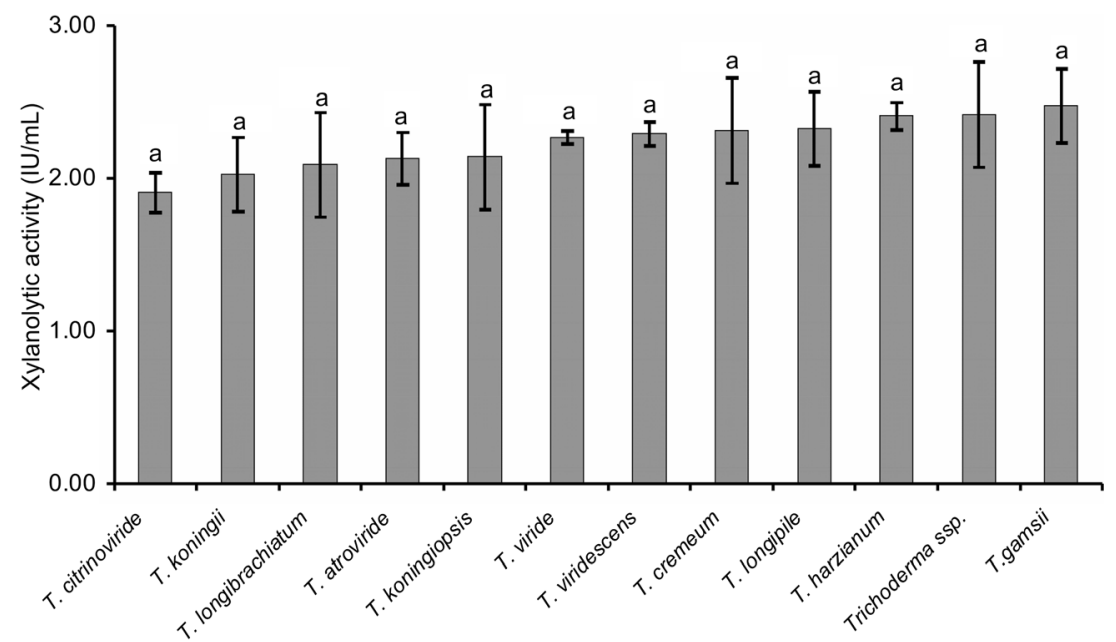

Fig. 3 Xylanase activity distribution for eight Trichoderma species. The same lower case letters indicate non-significant differences in xylanolitic activity among species. Trichoderma harzianum include isolates T. harzianum and T. atrobrunneum, belonging to the T. harzianum species complex. Trichoderma viridescens include isolates T. paraviridescens, $T$. trixiae and T. viridarium, belonging to the T. viridescens species complex. Bars represent mean \pm standard error of three independent analyses (assay of xylanase activity) for each strain 
(Hess 1965). The vegetation of the Gorce Mts is composed chiefly of deciduous and coniferous forests, in a great part primeval (Carpathian Primeval Forest) and natural (Loch and Armatys 2008). The most common species of trees are Picea abies (L.) H. Karst, Fagus sylvatica L., and Abies alba Mill., while admixture species include larch, elm, ash and grey alder (Loch and Armatys 2008). Whereas, the forests of the Tatra Mountains are dominated by Picea abies (L.) H. Karst with low occurrence Abies alba Mill. and Fagus sylvatica L. and isolated individuals of Pinus cembra L. and Larix decidua Mill. (Fleischer et al. 2009). Both the Gorce National Park and the Tatra National Park were characterized by a similar diversity of Trichoderma species. It is worth noting that the distribution of these species at the Tatra National Park (location C) was found as the least homogenous. It is worth recalling that in November 2004, spruce stands in the Tatra National Park on the area of 12,000 hectares were affected by a catastrophic windthrow and 1 year later (in July 2005) wildfire broke out on a part (220 ha) of this area (Fleischer et al. 2009; Kopecká and Nováèek 2009). This may have contributed to the decline of the originally present abundance of species dependent on forest, their diversity and redistribution in Tatra National Park (Fleischer et al. 2009; Kopecká and Nováèek 2009).

All of the 119 Trichoderma strains investigated in this study were isolated from pieces of wood with decay symptoms. Consequently, the question arose as to whether all these strains are able to participate in decomposition of particularly xylan and cellulose containing organic matter. The cellulolytic and xylanolytic activity assay is one of the approaches to the preliminary determination of the potential of the strains for enzymes production and has been widely used in many studies for screening of a broad spectrum of fungal isolates and environmental samples (Benoliel et al. 2013; Cianchetta et al. 2010; Delabona et al. 2012; Ja'afaru 2013). This preliminary screening showed that all Trichoderma species identified in the present study disclose the potential to degrade cellulose (Whatman No. 1 filter paper) and birch wood xylan under assay conditions used. The possibility of cellulase and hemicellulase complex formation by $T$. atroviride, T. citrinoviride, T. gamsii, T. harzianum, T. koningii, T. longibrachiatum, $T$. viride and $T$. viridescens complex, has already been stated in previous studies (Gusakov 2011; Strakowska et al. 2014; Targoński 1991). To the best of our knowledge, this is the first study revealing the ability of T. cremeum, $T$. longipile and $H$. parapilulifera towards cellulase and xylanase production. However, the results of this work revealed the same variability in the level of enzymatic activity among Trichoderma species and even among strains of the same species. It will be interesting to study further what causes these differences in hydrolytic activity among the isolates. The explanation of this question seems to be important due to the potential use of the tested strains for further biotechnological purposes.

The present study has shown the real potential of all Trichoderma species originating from wood with decay symptoms to produce cellulases and xylanases - the key enzymes in plant cell wall degradation, and thus to a saprotrophic style of nutrition. Interestingly, some of these species are known to be both saprotrophic and mycoparasitic or additionally exist as endophytes (T. gamsii, T. harzianum) and immunocompromised human pathogens, such as T. longibrachiatum (Druzhinina et al. 2011; Jaklitsch 2009) or T. gamsii (Rinu et al. 2014). However, there is still no definitive statement as to which of these species living on decaying wood is a strong saprotroph or strong mycoparasite or which species uses both ways of nutrition and what determines the switching between these two tropic strategies. The ability of Trichoderma to derive nutrients from other fungi mediated by mycoparasitism has been clearly investigated in species of T. harzianum, T. atroviride and T. viride (Druzhinina et al. 2011). Based on recent evolutionary studies, the mycoparasitic way of nutrition has also been deduced for T. cremeum, T. longipile, T. viridescens, T. koningii and T. koningiopsis, while T. citrinoviride, T. longibrachiatum and H. parapilulifera species are predicted to function as saprotrophs. According to Chaverri and Samuels (2013), the association of Trichoderma species with plants (saprotrophy, plant necrotrophy) has evolved at least twice (from mycoparasitism to saprotrophy: T. citrinoviride, T. longibrachiatum, $H$. parapilulifera) and then reversed to mycoparasitism possibly twice (from mycoparasitism to mycoparasitism by saprotrophism: T. atroviride, T. gamsii, T. viride, T. viridescens, T. koningii, T. koningiopsis). Chaverri and Samuels (2013) also observed that the habitat preference (decaying plants, soil, fungi, living plants) of Trichoderma has been gained or lost multiple times in the evolution of this genus and the majority of these changes have concerned the shift from decaying plant material to soil or fungi, from soil to endophyte and from fungi to decaying plant material. Xie et al. (2014) concluded that the development of a new way of nutrition is not only related to the decrease of nutritionrelated genes (as in the case of mycoparasitism-specific genes), but also to the increase of selection pressure on nutrition-related genes (as in the case of genes encoding the plant cell wall degrading enzymes).

Considering our findings with respect to genomic and transcriptomic studies and evolutionary investigations, it is only possible to infer the capacity of a single Trichoderma species to use any of these ecological strategies. However, further studies are needed to identify the key elements in the molecular repertoire required for balancing between the saprotrophic and mycoparasitic ways of nutrition of putative Trichoderma species. 
Acknowledgments This work was partially (morphological and molecular identification of Trichoderma isolates) supported by the Ministry of Science and Higher Education in Poland, Project No. NN310 203037. The authors would like to thank Professor Gary J. Samuels from the United States Department of Agriculture, Agricultural Research Service, Systematic Mycology and Microbiology Laboratory for its helpful comments on $T$. viridescens species complex identification.

Open Access This article is distributed under the terms of the Creative Commons Attribution 4.0 International License (http:// creativecommons.org/licenses/by/4.0/), which permits unrestricted use, distribution, and reproduction in any medium, provided you give appropriate credit to the original author(s) and the source, provide a link to the Creative Commons license, and indicate if changes were made.

\section{References}

Aro N, Pakula T, Penttila M (2005) Transcriptional regulation of plant cell wall degradation by filamentous fungi. FEMS Microbiol Rev 29: 19-739

Atanasova L, Le Crom S, Gruber S, Coulpier F et al. (2013) Comparative transcriptomics reveals different strategies of Trichoderma mycoparasitism. BMC Genomics 14:121

Belayneh Mulaw T, Kubicek CP, Druzhinina IS (2010) The rhizosphere of coffea arabica in its native highland forests of Ethiopia provides a niche for a distinguished diversity of Trichoderma. Diversity 2:527549

Benoliel B, Torres FA, de Moraes LM (2013) A novel promising Trichoderma harzianum strain for the production of a cellulolytic complex using sugarcane bagasse in natura. Springerplus 2:656. doi: 10.1186/2193-1801-2-656

Błaszczyk L, Popiel D, Chełkowski J, Koczyk G, Samuels GJ, Sobieralski K, Siwulski M (2011) Species diversity of Trichoderma in Poland. J Appl Genet 52:233-243

Błaszczyk L, Siwulski M, Sobieralski K, Frużyńska-Jóźwiak D (2013) Diversity of Trichoderma spp. causing Pleurotus green mould diseases in Central Europe. Folia Microbiol 58:325-333

Buee M, Reich M, Murat C, Morin E et al. (2009) 454 Pyrosequencing analyses of forest soils reveal an unexpectedly high fungal diversity. New Phytol 184:449-456

Carbone I, Kohn LM (1999) A method for designing primer sets for speciation studies in filamentous ascomycetes. Mycologia 91:553556

Chaverri P, Samuels GJ (2013) Evolution of habitat preference and nutrition mode in a cosmopolitan fungal genus with evidence of interkingdom host jumps and major shifts in ecology. Evolution 67:2823-2837

Chaverri P, Castlebury LA, Samuels GJ, Geiser DM (2003) Multilocus phylogenetic structure within the Trichoderma harzianum/ Hypocrea lixii complex. Mol Phylogenet Evol 27:302-313

Chaverri P, Branco-Rocha F, Jaklitsch WM, Gazis RO, Degenkolb T, Samuels GJ (2015) Systematics of the Trichoderma harzianum species complex and the re-identification of commercial biocontrol strains. Mycologia. doi:10.3852/14-147

Cianchetta S, Galletti S, Burzi PL, Cerato C (2010) A novel microplatebased screening strategy to assess the cellulolytic potential of Trichoderma strains. Biotechnol Bioeng 107:461-468

Delabona Pda S, Farinas CS, da Silva MR, Azzoni SF, Pradella JG (2012) Use of a new Trichoderma harzianum strain isolated from the Amazon rainforest with pretreated sugar cane bagasse for on-site cellulase production. Bioresour Technol 107:517-521
Doohan FM, Parry DW, Jenkinson P, Nicholson P (1998) The use of species-specific PCR-based assays to analyse Fusarium ear blight of wheat. Plant Pathol 47:197-205

Druzhinina IS, Kopchinskiy AG, Komon M, Bissett J, Szakacs G, Kubicek CP (2005) An oligonucleotide barcode for species identification in Trichoderma and Hypocrea. Fungal Genet Biol 42:813828

Druzhinina IS, Komoń-Zelazowska M, Atanasova L, Seidl V, Kubicek CP (2010) Evolution and ecophysiology of the industrial producer Hypocrea jecorina (Anamorph Trichoderma reesei) and a new sympatric agamospecies related to it. PLoS ONE 5, e9191. doi:10.1371/ journal.pone.0009191

Druzhinina IS, Seidl-Seiboth V, Herrera-Estrella A, Horwitz BA et al. (2011) Trichoderma: the genomics of opportunistic success. Nat Rev Microbiol 16:749-759

Druzhinina IS, Shelest E, Kubicek CP (2012) Novel traits of Trichoderma predicted through the analysis of its secretome. FEMS Microbiol Lett 337:1-9

Eveleigh DE, Mandels M, Andreotti R, Roche C (2009) Measurement of saccharifying cellulase. Biotechnol Biofuels 2:21

Fleischer P, Koreň M, Škvarenina J, Kunca V (2009) Risk assessment of the Tatra mountains forest. In: Střelcová K et al. (eds) Bioclimatology and natural hazards. Springer, Netherlands, pp 145-154

Friedl MA, Druzhinina IS (2012) Taxon-specific metagenomics of Trichoderma reveals a narrow community of opportunistic species that regulate each other's development. Microbiology 158:69-83

Fukasawa Y, Osono T, Takeda H (2005) Decomposition of Japanese beech wood by diverse fungi isolated from a cool temperate deciduous forest. Mycoscience 46:97-101

Fukasawa Y, Osono T, Takeda H (2011) Wood decomposing abilities of diverse lignicolous fungi on nondecayed and decayed beech wood. Mycologia 103:474-482

Gams W, Bisset J (1998) Morphology and identification of Trichoderma. In: Harman GE, Kubicek CP (eds) Trichoderma and Gliocladium, vol 1. Taylor and Francis, London, pp 3-34

Ghose TK (1987) Measurement of cellulase activities. Pure Appl Chem 59:257-268

Gusakov AV (2011) Alternatives to Trichoderma reesei in biofuel production. Trends Biotechnol 29:419-425

Hagn A, Wallisch S, Radl V, Munch JC, Schloter M (2007) A new cultivation independent approach to detect and monitor common Trichoderma species in soils. J Microbiol Methods 69:86-92

Hess M (1965) Vertical climatic zones in the Polish Western Carpathians, vol 11. Zeszyty Naukowe UJ-Prace Geograficzne, Kraków (in Polish with English summary)

Hess M (1996) Climate. In: Mirek Z, Głowaciński Z, Klimek K, PiekośMirkowa H. (eds) The nature of the Tatra National Park. Tatrzański Park Narodowy, Zakopane-Kraków, pp 53-68 (in Polish with English summary)

Hoyos-Carvajal L, Orduz S, Bissett J (2009) Genetic and metabolic biodiversity of Trichoderma from Colombia and adjacent neotropic regions. Fungal Genet Biol 46:615-631

Ja'afaru MI (2013) Screening of fungi isolated from environmental samples for xylanase and cellulase production. ISRN Microbiology, ID 283423, doi: $10.1155 / 2013 / 283423$

Jaklitsch WM (2009) European species of Hypocrea part I. The greenspored species. Stud Mycol 63:1-91

Jaklitsch WM (2011) European species of Hypocrea part II: species with hyaline ascospores. Fungal Divers 48:1-250

Jaklitsch WM, Komon M, Kubicek CP, Druzhinina IS (2005) Hypocrea voglmayrii sp. nov. from the Austrian Alps represents a new phylogenetic clade in Hypocrea/Trichoderma. Mycologia 97:1365-1378

Jaklitsch WM, Samuels GJ, Dodd SL, Lu BS, Druzhinina IS (2006) Hypocrea rufa/Trichoderma viride: a reassessment, and description 
of five closely related species with and without warted conidia. Stud Mycol 56:135-177

Jaklitsch WM, Samuels GJ, Ismaiel A, Voglmayr H (2013) Disentangling the Trichoderma viridescens complex. Persoonia 31:112-146

Jeleń H, Błaszczyk L, Chełkowski J, Rogowicz K, Strakowska J (2014) Formation of 6-n-pentyl-2H-pyran-2-one (6-PAP) and other volatiles by different Trichoderma species. Mycol Progr 13:589-600

Klein D, Eveleigh DE (1998) Tichoderma and Gliocladium. In: Harman GE, Kubicek CP (eds) Trichoderma and Gliocladium, vol 1. Taylor and Francis, London, pp 57-69

Kopchinskiy A, Komon M, Kubicek CP, Druzhinina IS (2005) TrichoBLAST: a multilocus database for Trichoderma and Hypocrea identifications. Mycol Res 109:657-660

Kopecká M, Nováèek J (2009) Forest fragmentation in the Tatra Region in the period 2000-2006. Landform Anal 10:58-63

Kubicek CP (2013) Systems biological approaches towards understanding cellulase production by Trichoderma reesei. J Biotechnol 163: $133-142$

Kubicek CP, Bissett J, Druzhinina I, Kullnig-Gradinger C, Szakacs G (2003) Genetic and metabolic diversity of Trichoderma: a case study on South-East Asian isolates. Fungal Genet Biol 38:310-319

Kubicek CP, Komon-Żelazowska M, Druzhinina IS (2008) Fungal genus Hypocrea/Trichoderma: from barcodes to biodiversity. J Zhejiang Univ Sci B 9:753-763

Kubicek CP, Herrera-Estrella A, Seidl-Seiboth V, Martinez DA et al. (2011) Comparative genome sequence analysis underscores mycoparasitism as the ancestral life style of Trichoderma. Genome Biol 12:R40

Lieckfeldt E, Kullnig CM, Samuels GJ, Kubicek CP (2000) Sexually competent, sucrose- and nitrate-assimilating strains of Hypocrea jecorina (Trichoderma reesei, Hypocreales) from South American soils. Mycologia 92:374-384

Lim YW, Kim BK, Kim C, Jung HS et al. (2010) Assessment of soil fungal communities using pyrosequencing. J Microbiol 48:284-289

Loch J, Armatys P (2008) Primeval Carpathian forest in the Gorce Mts.history, state of preservation and problems of protection. Rocz Bieszczadzkie 16:109-124 (in Polish with English summary)

López-Quintero CA, Atanasova L, Franco-Molano AE, Gams W, Komon-Zelazowska M, Theelen B, Müller WH, Boekhout T, Druzhinina I (2013) DNA barcoding survey of Trichoderma diversity in soil and litter of the Colombian lowland Amazonian rainforest reveals Trichoderma strigosellum sp. nov. and other species. Antonie Van Leeuwenhoek 104:657-674

Meincke R, Weinert N, Radl V, Schloter M et al (2010) Development of a molecular approach to describe the composition of Trichoderma communities. J Microbiol Methods 80:63-69

Miczyński J (2006) Climate In: Różański W (eds.) The Gorce National Park-25 years of nature and cultural heritage protection in the Gorce Mts, GPN, Poręba Wielka, pp. 33-57 (in Polish with English summary)

Migała K (2005) Climatic belts in the European mountains and the issue of global changes. Acta Universitatis Wratislaviensis, 2718, Studia Geogr. Vol. 78, Wrocław, pp 149 (in Polish with English summary)
Migheli Q, Balmas V, Komoñ-Zelazowska M, Scherm B, Fiori S, Kopchinskiy AG, Kubicek CP, Druzhinina IS (2009) Soils of a Mediterranean hot spot of biodiversity and endemism (Sardinia, Tyrrhenian Islands) are inhabited by pan-European, invasive species of Hypocrea/Trichoderma. Environ Microbiol 11:35-46

Miller GL (1959) Use of dinitrosalicylic acid reagent for determination of reducing sugar. Anal Chem 31:426-428

Nirenberg HI (1976) Untersuchungen über die morphologische und biologische Differenzierung in der Fusarium-Sektion Liseola. Mitt. Biol. Bundesanst. Land- Forstwirtsch., Berl.-Dahl. 169:1-117

Rinu K, Sati P, Pandey A (2014) Trichoderma gamsii (NFCCI 2177): a newly isolated endophytic, psychrotolerant, plant growth promoting, and antagonistic fungal strain. J Basic Microbiol 54:408-417

Rossman AY (1996) Morphological and molecular perspectives on systematics of the Hypocreales. Mycologia 88:1-19

Samuels GJ (2006) Trichoderma: systematics, the sexual state, and ecology. Phytopathology 96:195-206

Savva Y, Oleksyn J, Reich PB, Tjoelker MG, Vaganov EA, Modrzynski J (2006) Interannual growth response of Norway spruce to climate along an altitudinal gradient in the Tatra Mountains, Poland. Trees 20:735-746

Shannon CE (1948) A mathematical theory of communication. Bell Syst Tech J 27: 379-423 and 623-656

Simpson EH (1949) Measurement of diversity. Nature 163:688

Strakowska J, Błaszczyk L, Chełkowski J (2014) The significance of cellulolytic enzymes produced by Trichoderma in opportunistic lifestyle of this fungus. J Basic Microbiol 54:S2-S13

Tamura K, Dudley J, Nei M, Kumar S (2007) MEGA4: Molecular Evolutionary Genetics Analysis (MEGA) software version 4.0. Mol Biol Evol 24:1596-1599

Targoński Z (1991) Biosyntesis of cellulases and ksylanases and lytic enzymes by the use of Trichoderma reesei QM 9414 and Trichoderma viride F-19. Biotechnologia 2:50-58

Thompson JD, Higgins DG, Gibson TJ (1994) CLUSTAL W: improving the sensitivity of progressive multiple sequence alignment through sequence weighting, position-specific gap penalties and weight matrix choice. Nucleic Acids Res 22:4673-4680

UNESCO (2011) The Krkonoše/Karkonosze Transboundary Biosphere Reserve (BRKK). UNESCO Biosphere Reserve on the CzechPolish boundary. The United Nations Educational, Scientific and Culture Organization, pp 36

White TJ, Bruns T, Lee S, Taylor JW (1990) Amplification and direct sequencing of fungal ribosomal RNA genes for phylogenetics. In: Innis MA, Gelfand DH, Shinsky JJ, White TJ (eds) PCR protocols: a guide to methods and applications. Academic, San Diego, pp 315322

Xie B-B, Qin Q-L, Shi M, Chen L-L, Shu Y-L, Luo Y, Wang X-W, Rong J-C, Gong Z-T et al. (2014) Comparative genomics provide insights into evolution of Trichoderma nutrition style. Genome Biol Evol 6: 379-390

Zhang CL, Druzhinina IS, Kubicek CP, Xu T (2005) Trichoderma biodiversity in China: evidence for a North to South distribution of species in East Asia. FEMS Microbiol Lett 251:251-257 